\title{
Shared decision-making in prostate cancer screening: A review.
}

\author{
Miguel Ángel Acosta-Benito \\ Doctor in Mar Báltico Primary Care Centre, Madrid's Public Health Service, Spain.
}

\begin{abstract}
Introduction: Actual guidelines for prostate cancer screening recommend shared decisionmaking in this subject; due to the lack of consensus about if this screening has benefits or has not. Primary care centres are the usual place for this activity. The aim of this revision is to analyze interventions made on share decision-making and the principal problems found in this process.

Materials and methods: A review of the literature was made through a search in Medline Database. Works that evaluated someway the shared decision-making process were obtained. Principal topics on the subject were extracted and summarized.

Results: Eleven works were selected. Most of them versed on the difficulties found in shared decision-making process as preformed ideas on screening effectiveness, lack of knowledge on the last guidelines by physicians, ignorance on real morbidity associated to prostate cancer diagnosis procedures or on mortality related to prostate cancer. There were found some intervention programmes based on short pieces of advice before the medical visit for patients and/or doctors that were positive for activating discussion on the subject.

Conclusion: Doctors need to learn about methods for share decision-making on prostate cancer screening, starting for knowing the last guidelines' recommendations. Social view of PSA screening must be confronted with structured information about the pros and cons of it. Concise information is useful for this purpose, through written booklets, videos or webbased programmes.
\end{abstract}

Keywords: Early detection of cancer, Prostate cancer, Clinical decision-making.

Accepted September 10, 2016

\section{Introduction}

Prostate cancer is the most commonly-diagnosed non-skin neoplasia in men. Since early in the 1990 s, prostate-specific antigen (PSA) has been used as a diagnostic method for this disease, and also for its follow-up. Recent studies made from the observation of incidence, prevalence and mortality due to prostate cancer during these 26 years have showed that the screening using PSA has led to an increased detected incidence. Although metastasis rate in the time of diagnosis decreased by using this tool, the important decline in mortality had more to do with treatment than with screening [1]. Several studies, as the ERSPC [2], showed that PSA screening was a useful way of improving the surveillance of prostate cancer, if confronted with no screening. On the other hand, the PLCO trial noted that structured screening was not better than opportunistic, as men in both arms of the trial had a very low mortality rate [3]. Current guidelines suggest prostate cancer screening must focus on the individual risk of each patient, and be used in those that have a life expectancy greater than 10-15 years life. The decision to perform screening implies that patient receives correct and complete information, and the decision is shared between him and the doctor $[4,5]$.

Primary care physicians are usually responsible for informing patients about screening for various diseases, including prostate cancer. Usually have to face preformed ideas or advertising campaigns that make the patient go with a judge on screening for prostate cancer (PCS). This represents a difficulty to avoid unnecessary screening, over diagnosis and overtreatment derivatives thereof, as well as costs derivate from them. The aim of this revision is to sum up the evidence in programmes in Primary Care directed to apply shared-decision making in screening for prostate cancer. Principal topics, barriers and tools will be resumed in order to analyse the principal problems in shared decision making process and ways of coping them. 


\section{Materials and Methods}

A revision of the literature about this subject has been made, in order to analyse the investigations made on shared-decision making in screening for prostate cancer in primary care.

\section{Information Sources}

A Medline search strategy was developed, by using the search form "Primary Care" and "Shared decision making" AND "Prostate cancer".

\section{Eligibility Criteria}

Publications needed to meet specific criteria for being considerated. They should consider screening for prostate cancer by using methods than can be applied by Family Medicine Physicians, or explored the consequences of this screening (principally Prostate Specific Antigen). Another requirement was that shared-decision making must be analysed in some way (intervention studies, description of problems on the subject, information that must be given for the shared decision-making process...) and specifically described.

\section{Study Selection}

The reading of the title and the abstract of all the results of the search was made, proceeding to read the complete articles that complied the exposed criteria. The review was made by two independent investigators, resolving the conflicts by consensus. Topics on selected studies were classified as they appeared, in order to summarize the information on shared decision-making in prostate cancer. Number of participants and outcomes measured were recorded.

\section{Analysis}

A description of the literature on the subject was made, trying to resume and order it.

\section{Results}

\section{Study Selection}

A PRISMA diagram explains the flow of the studies through the review (Figure 1). The automatic search gave 18 articles for consideration, but just 11 met the eligibility criteria. Among the discarded, 5 did not expose any intervention, 1 did not separate data from colorectal cancer screening or prostate cancer screening and another was a resume of the international guidelines.

\section{Characteristics of the Studies}

Studied population, target, principal outcomes and main results of the selected studies are described in Table 1.

\section{Principal Topics}

\section{Life Expectancy from Screening}

$\mathrm{Xu}$ et al. made an investigation that, although studied men with local prostate cancer after diagnosis, is useful to understand the ideas on survival that this entity presents. Most men thought that they had a greater chance to survive

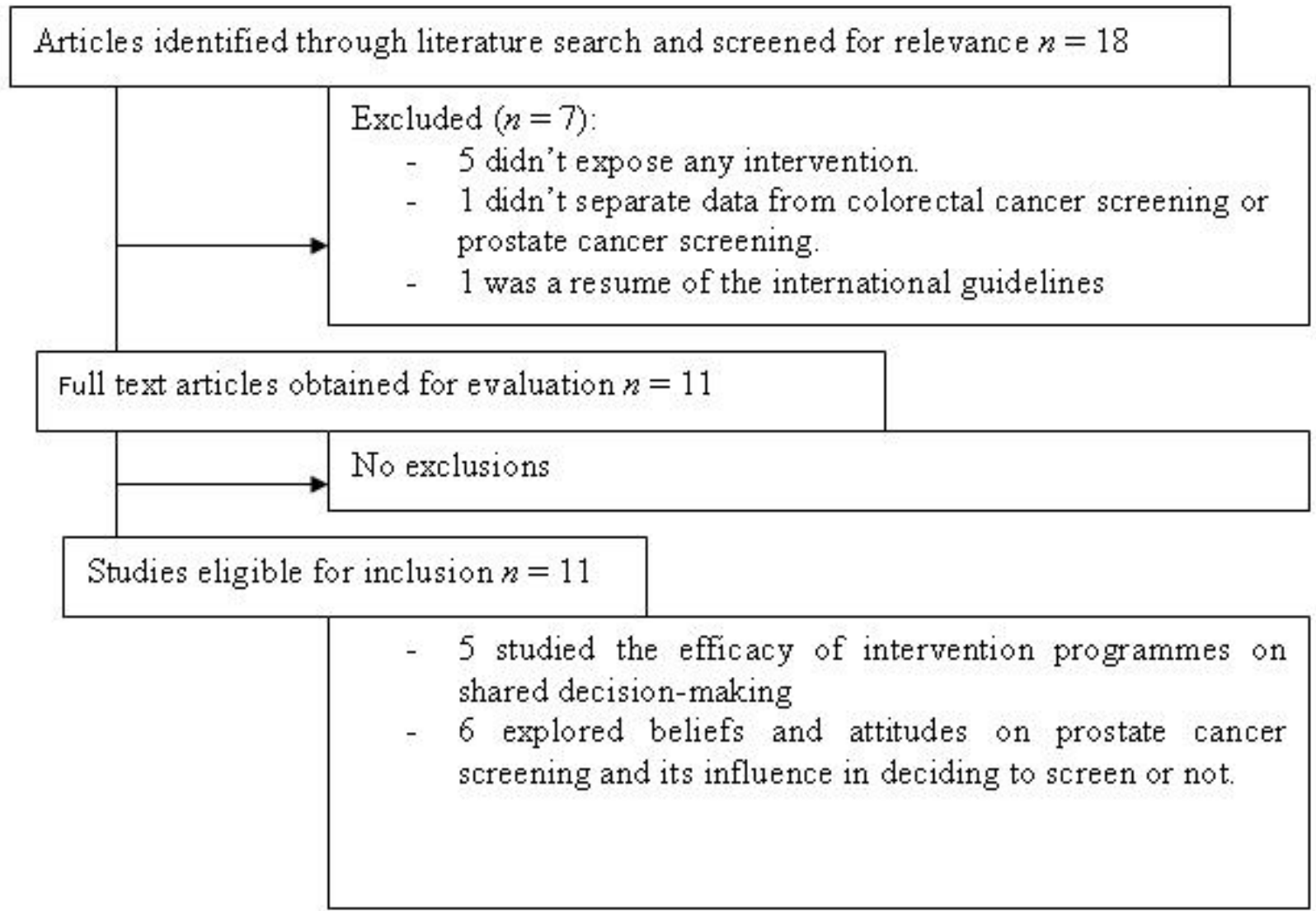

Figure 1. A PRISMA diagram explains the flow of the studies through the review 
Table 1. Resume of the evidence in shared decision-making in prostate cancer screening

\begin{tabular}{|c|c|c|c|c|}
\hline \multicolumn{5}{|c|}{ Resume of the evidence in shared decision-making in prostate cancer screening } \\
\hline Author & Population & \begin{tabular}{|l|l} 
Target & C \\
\end{tabular} & Outcome & Principal Results \\
\hline $\begin{array}{l}\mathrm{Xu} \text { et al. } \\
{[6]}\end{array}$ & $\begin{array}{l}\text { Patients with } \\
\text { localized prostate } \\
\text { cancer, } 75 \text { years } \\
\text { old or younger that } \\
\text { have chosen their } \\
\text { treatment. } \\
\quad(n=266)\end{array}$ & $\begin{array}{c}\text { Describe survival } \\
\text { expectations }\end{array}$ & $\begin{array}{l}\text { Self-reported life } \\
\text { expectancy }\end{array}$ & $\begin{array}{l}\text { - Without treatment: } 33 \% \text { of patients thought that } \\
\text { they would live less than } 5 \text { years, } 41 \% 5 \text { to } 10 \text { years, } \\
21 \% 10 \text { to } 20 \text { years and } 5 \% \text { more than } 20 \text { years. } \\
\text { - With their chosen treatment: } 3 \% \text { of patients thought } \\
\text { that they would live less than } 5 \text { years, } 9 \% 5 \text { to } 10 \\
\text { years, } 33 \% 10 \text { to } 20 \text { years, and } 55 \% \text { more than } 20 \\
\text { years. } \\
\text { - Men who chose surgery or radiation expected to } \\
\text { have a better survival rate. } \\
\text { - Age, general health perception and perceived } \\
\text { cancer-seriousness influenced in the life expectancy, } \\
\text { but the tumour risk stratification not. }\end{array}$ \\
\hline $\begin{array}{l}\text { Barry et al. } \\
\text { [7] }\end{array}$ & $\begin{array}{l}\text { Patients suitable } \\
\text { for PSA screening } \\
\text { according to } \\
\text { doctor's decision } \\
\quad(\mathrm{n}=1041)\end{array}$ & $\begin{array}{l}\text { Describe men's PSA } \\
\text { screening preferences } \\
\text { before and after viewing } \\
\text { a decision aid (video) }\end{array}$ & $\begin{array}{l}\text { PSA screening } \\
\text { yes/no }\end{array}$ & 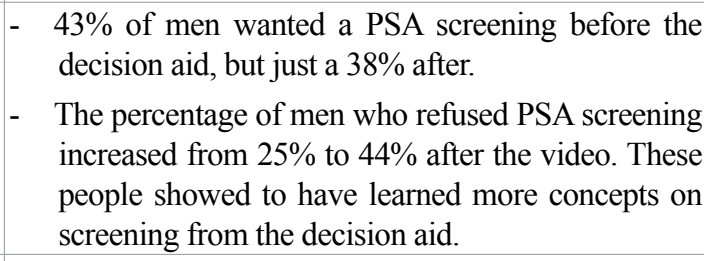 \\
\hline $\begin{array}{l}\text { Wilkes et } \\
\text { al. [11] }\end{array}$ & $\begin{array}{l}\text { Men } 55-65 \text { years- } \\
\text { old without severe } \\
\text { comorbidity. } \\
\quad(n=581)\end{array}$ & $\begin{array}{l}\text { Describe men's PSA } \\
\text { screening preferences } \\
\text { before and after a short } \\
\text { interactive educational } \\
\text { Web-based program. }\end{array}$ & $\begin{array}{l}\text { Patients' } \\
\text { perception of } \\
\text { shared decision } \\
\quad \text { making }\end{array}$ & $\begin{array}{l}\text { - Activating patient in order to discuss PSA } \\
\text { screening helps physicians to be more neutral in } \\
\text { their opinion. } \\
\text { - Physician's impression on screening before } \\
\text { patient's visit influences the final decision. }\end{array}$ \\
\hline $\begin{array}{l}\text { Feng et al. } \\
\text { [9] }\end{array}$ & $\begin{array}{l}\text { Internal Medicine } \\
\text { and Family } \\
\text { Medicine Doctors } \\
\quad(\mathrm{n}=118)\end{array}$ & $\begin{array}{l}\text { Describe physician } \\
\text { behaviors after receiving } \\
\text { a specific formation }\end{array}$ & $\begin{array}{l}\text { OPTION scale } \\
\text { (Kaplan's shared } \\
\text { decision-making } \\
\quad \text { scale) }\end{array}$ & $\begin{array}{l}\text { - Physicians that received specific education on } \\
\text { prostate cancer screening improved their shared- } \\
\text { decision behaviour: were more likely to mention no } \\
\text { screening or other screening options. }\end{array}$ \\
\hline $\begin{array}{l}\text { Wilkes et } \\
\text { al. [8] }\end{array}$ & $\begin{array}{l}\text { Panellist represented } \\
\text { diverse specialties, } \\
\text { disciplines and } \\
\text { market sectors. } \\
(\mathrm{n}=16)\end{array}$ & $\begin{array}{l}\text { Identify priorities } \\
\text { to promote evidence- } \\
\text { based, value-concordant } \\
\text { decisions }\end{array}$ & $\begin{array}{l}\text { Kind of strategy, } \\
\text { efficacy and effort. }\end{array}$ & $\begin{array}{l}\text { Evidence based- aids using technology and } \\
\text { methods as pre-visit decision support, training for } \\
\text { physicians, and clarifying messages are techniques } \\
\text { that might be useful in shared decision-making. }\end{array}$ \\
\hline $\begin{array}{l}\text { Volks et al. } \\
{[18]}\end{array}$ & $\begin{array}{l}\text { Primary } \\
\text { care physicians } \\
\quad(\mathrm{n}=246)\end{array}$ & $\begin{array}{l}\text { Describe prescreening } \\
\text { discussions about the } \\
\text { controversy on prostate } \\
\text { cancer screening. }\end{array}$ & $\begin{array}{l}\text { Discuss benefits } \\
\text { and risk of } \\
\text { prostate cancer } \\
\text { screening YES/ } \\
\text { NO }\end{array}$ & $\begin{array}{l}\text { - Doctors who discussed about prostate cancer } \\
\text { screening believed in scientific controversy about } \\
\text { this subject, whereas doctors who directly ordered } \\
\text { PSA thought that patient's desired on being } \\
\text { screened was more important. } \\
\text { - Concerns about medico-legal problems related to } \\
\text { screening were more common among doctor that } \\
\text { discussed screening. }\end{array}$ \\
\hline Maffei [13] & $\begin{array}{c}\text { Patients/physicians } \\
\text { encounters } \\
(\mathrm{n}=62)\end{array}$ & $\begin{array}{l}\text { Identify the information } \\
\text { needs of male patients } \\
\text { in prostate cancer } \\
\text { screening }\end{array}$ & $\begin{array}{l}\text { Main themes of } \\
\text { discussion }\end{array}$ & $\begin{array}{l}\text { - The principal themes of discussion that needed to be } \\
\text { cleared for patients to understand were: confusion } \\
\text { between prostate and colon cancer screening, } \\
\text { mortality rate for prostate cancer, understanding } \\
\text { the controversy surrounding the screening test and } \\
\text { postponing the decision about getting screened or not. }\end{array}$ \\
\hline $\begin{array}{l}\text { Davis et al. } \\
{[15]}\end{array}$ & $\begin{array}{l}\text { Primary Care } \\
\text { Academic and } \\
\text { community } \\
\text { physicians and } \\
\text { residents. } \\
\quad(n=135)\end{array}$ & $\begin{array}{l}\text { Describe primary care } \\
\text { physician's attitudes } \\
\text { and factors that may } \\
\text { influence the shared } \\
\text { decision-making process }\end{array}$ & $\begin{array}{l}\text { 26- item survey } \\
\text { that addressed: } \\
\text { physicians' } \\
\text { characteristics, } \\
\text { attitudes about } \\
\text { screening and } \\
\text { report of the SDM } \\
\text { process for PCS }\end{array}$ & $\begin{array}{l}\text { - Community physicians thought more commonly } \\
\text { that PSA screening has a good specificity and } \\
\text { sensitivity, and that provider's make a malpractice } \\
\text { if they don't screen for prostate cancer and it is } \\
\text { discovered afterwards. } \\
\text { - } \\
\text { Academic physicians and residents were more } \\
\text { likely not to recommend PSA screening for } \\
\text { asymptomatic men over 50. } \\
\text { - Most physicians preferred a shared decision- } \\
\text { making process or let the patient take the decision. }\end{array}$ \\
\hline
\end{tabular}




\begin{tabular}{|c|c|c|c|c|}
\hline $\begin{array}{l}\text { McFall et } \\
\text { al. [14] }\end{array}$ & $\begin{array}{l}\text { Men in age of } \\
\text { being screened for } \\
\text { prostate cancer, } \\
\text { age depending on } \\
\text { ethnicity. Women } \\
\text { the same age. } \\
\qquad(n=90)\end{array}$ & $\begin{array}{l}\text { Comparing beliefs and } \\
\text { perspectives of African } \\
\text { American, } \\
\text { Hispanic, and non- } \\
\text { Hispanic White men and } \\
\text { women. }\end{array}$ & $\begin{array}{l}\text { Principal items } \\
\text { of discussion and } \\
\text { beliefs. }\end{array}$ & $\begin{array}{l}\text { - Participants named as risk factors age, race, } \\
\text { genetics, sexual activity and lifestyle. } \\
\text { - Most participants thought that symptoms appear } \\
\text { usually in early stage. } \\
\text { - They didn't have a common idea for screening, } \\
\text { and were not aware of its controversy. Opinions on } \\
\text { shared decision-making varied from supporting it, } \\
\text { recognizing that patients' behaviour might change, } \\
\text { to others that preferred to follow the experts' } \\
\text { opinion. } \\
\text { - Women were more concerned about their husbands' } \\
\text { health, and more interested in screening. }\end{array}$ \\
\hline $\begin{array}{l}\text { Woolf et al. } \\
{[16]}\end{array}$ & $\begin{array}{c}\text { Men aged 50- } \\
70 \text { years who } \\
\text { scheduled a health } \\
\text { maintenance } \\
\text { examination }\end{array}$ & $\begin{array}{c}\text { Examine the desired and } \\
\text { actual level of patient } \\
\text { control over screening } \\
\text { decisions }\end{array}$ & $\begin{array}{l}\text { Questionnaire } \\
\text { on background } \\
\text { knowledge, } \\
\text { discussion, PSA } \\
\text { test was ordered. }\end{array}$ & $\begin{array}{l}\text { - Patients prefer a shared approach to the PSA } \\
\text { decision but report greater personal control when } \\
\text { the decision is actually made. }\end{array}$ \\
\hline $\begin{array}{l}\text { Myers et al. } \\
{[12]}\end{array}$ & $\begin{array}{l}\text { male patients } \\
\text { eligible for prostate } \\
\text { cancer screening } \\
\quad(n=313)\end{array}$ & $\begin{array}{l}\text { Assess the impact of } \\
\text { a mediated decision } \\
\text { support intervention }\end{array}$ & $\begin{array}{l}\text { Participant } \\
\text { knowledge was } \\
\text { measured on } \\
\text { baseline and } \\
\text { endpoint surveys } \\
\text { with } 10 \text { items }\end{array}$ & $\begin{array}{l}\text { - Prostate cancer screening knowledge at baseline is } \\
\text { low and that knowledge at endpoint had increased } \\
\text { among men in both study groups, but more in the } \\
\text { group that received assessment before visiting their } \\
\text { physician. } \\
\text { - The intervention didn't improve decisional conflict. }\end{array}$ \\
\hline
\end{tabular}

if they were treated with surgery or radiotherapy, and gave no importance to the actual stratification system [6].

\section{Effects of Decision Aid Programmes Applied to Patients}

Barry et al. analysed the effect of systematic information about prostate cancer by using a $31 \mathrm{~min}$ long video that was given to men who could be screened. They visualized the information outside the medical centre. Participants filled a survey before and after receiving the decision aid. Results demonstrated that the number of men who decided to continue with the screening by using PSA decreased, and the number of people who refused the screening increased greatly. The video mostly helped men who were not sure about the screening before watching it, guiding them to not to get their PSA measured [7].

\section{Interventions to Improve Physicians' Skills for the Shared Decision-Making Process}

If any intervention is important, that is physicians' education. Wilkes et al used a $2.30 \mathrm{~min}$ long web-based educational programme given to patients and another different for doctors. They didn't find any difference in perception of shared-decision making, but demonstrated that improving education of both parts led to discuss the pros and cons of screening. Changing doctor's behaviour through actualised information is vital to promote shareddecision making [9].

Well-informed physicians make more patient-centered interviews, and explain better the advantages and disadvantages of screening. They ask for patients' previous ideas, perspectives and experiences more than doctors that received usual education. Although influence in PSA screening was not measured, results show that changing physician's attitude may change clinical practice [9].

Professional's beliefs on screening influence the shared decision-making process. Doctors who understand that the screening has not showed strong benefits and are concerned about the potential risks of it, tend to inform patients better than those who are not so well informed. Physicians who consider that discuss about screening is useless because they cannot change patients' opinion and are less concerned about the medico-legal risks associated to prostate cancer screening [10].

\section{Principal Information that Must Contain a Shared Decision-Making Process}

A panel of experts composed by physicians of different specialities, patients and other actors involved in prostate cancer screening defined that the multidisciplinary analysis of evidence was crucial to help physicians and patients in the prostate cancer screening, as each professional had a different point of view of it. For example, urologist or oncologist were more concerned about severity of cancer and the benefits of screening on saving lives, but primary care physicians worried about side effects of treatments. Patients complained about the lack of information on disadvantages of prostate cancer screening. Anyway, it seemed that technology-based aids using social media, with simple messages can be helpful, more if it is focused in patient outcomes. Another helpful action is increasing the time for discussion [11]. Not all the interventions designed have been useful, so the aid programme must be planned carefully [12].

As prostate cancer screening is a wide subject to 
be explained, it is possible that some items must be underlined in the interviews with patients. Maffie identified that confusion between colorectal and prostate cancer was common, that patients needed no clarify the advantages and disadvantages of screening test and that beliefs on prostate cancer as a high-mortality illness must be discussed. Moreover, it was important for patients have time to take the decision, postponing it to further moment if desired [13].

McFall et al. identified some other factors that contribute to misleading in prostate cancer screening. In a study that tried to understand beliefs on this subject among men in screening-age and woman married with men in this age, they found that most people thought that this kind of cancer had symptoms in early stages, and had little knowledge about screening controversy. In the other hand, they assumed that prostate cancer is related to age, genetics and race [14].

\section{Barriers to the Process of Share Decision-Making}

Davis et al. analysed physicians' attitudes and other factors that influenced the shared decision-making process. First of all, they found differences between the attitude of community doctors and the one of academic doctors or residents. The second ones were more likely not to screen asymptomatic men over 50 , and were concerned about the effectiveness of PSA screening according to the actual state of the question. Physicians that ended their academic studies more than 15-20 years ago, thought that PSA screening has a good specificity and sensitivity, and ordered in a more paternalistically attitude an annual screening for their patients. Health priorities, acute problems, time constrains, patient interest and malpractice concerns were other factors that influence the shared decision-making process [15].

Another handicap for the shared decision-making process comes with the preformed idea of patients. Although most men would like to hear doctor's opinion, men who had decided before the visit to their physician to be tested maintain their decision. In those men, information or other considerations told by doctors are not useful to change their decision [16].

\section{Discussion}

Men with local prostate cancer with a Gleason score 5 or under have a mortality risk of less than $10 \%$ [4]. Some other studies have showed that observed survival in patients with Gleason $<10$ and low or medium risk prostate cancer is similar in those treated with radical prostatectomy or watchful waiting [17]. As most prostate cancer detected by PSA screening are localised it is important that patients have information on their individual risk and possible survival depending on the different treatment options.

It faces the beliefs of many patients, who think that mortality associated with prostate cancer detected through screening with PSA is high [6], misleading that is usually a located disease. Knowledge on shared Decision-making process must be acquired by physicians. As we come from paternalist models, share decision make doctors need to be trained in discussion skills and translate part of the responsibility of the process to patients. Nowadays, concepts and skills on share decision-making can be easily reached through web-based courses that have demonstrated to be efficient on this purpose. Doctors should clarify doubts and attend to patients' values in order to explain the actual situation on prostate cancer screening and guide them through the decision, respecting their final option [18].

Current guidelines suggest not make prostate cancer screening in men over 65 years. However, most of the examinations with PSA are done in older men, while the population that potentially could benefit from such screening (considering the existing controversy) would be men between 55 and 64 years [4]. Moreover, patients need to know that positive prostate cancer biopsy is found only in a $30-40 \%$ of men with elevated PSA in the screening, and that there are potential risks on these complementary procedures. These harms include urinary incontinence, sexual impairment or anxiety, among others [19].

Interventions examined in this review used short information aids in order to give practical advises to patients y/or doctor before deciding be screened or not for prostate cancer $[7,10]$. There are other investigations that support this kind of short educational programmes as they give concise information. Some important values for patients in these pieces of advice include: summary of the morbidity and mortality attributed to the process that is proposed to screen, clear statement of the benefits and disadvantages of the procedure, and identifiable and relevant sources of information [20].

It is important to fight inertia among physicians, apart from constant learning of renewed guidelines. One way of affronting this problem is by generating automatic information on screening that must be given to patients before the visit. It has been proved as an effective way of generating discussion on the matter and shared decisionmaking [21]. It can be useful as well for confronting preformed ideas that patient may have on prostate cancer screening, as them are one of the barriers of shared decision-making process [17].

\section{Conclusion}

Although shared decision-making is claimed as the proper way of confronting prostate cancer screening, it has been demonstrated that physicians need special training on it [9]. It can be acquired through web-based programmes [12]. The shared decision-making process needs simple and well-defined information, supported by strong evidence. This information must reach patients before their visit to the Primary Care doctor in order to discuss about prostate cancer screening during the visit [11]. 
Actual evidence underlines that preformed ideas, available wrong information ${ }^{6}$, bad physicians' agenda organization and ignorance on current guidelines are some of the barriers that shared decision-making has [16]. Interventions based on well-structured information (through short written pieces of advice, videos or web-based programmes) are useful for improving the shared decision-making process in prostate cancer screening $[7,8,12]$. In this way, we can avoid side effects of diagnostic procedures, decrease costs of unnecessary medical acts and empower people to take care of their own health.

\section{References}

1. Dickinson J, Shane A, Tonelli M, et al. Trends in prostate cancer incidence and mortality in Canada during the era of prostate-specific antigen screening. CMAJ Open 2016; 4: E73-E79.

2. Schroder FH, Hugosson J, Roobol MJ, et al. Screening and prostate cancer mortality: Results of the European randomised study of screening for prostate cancer (ERSPC) at 13 years follow-up. Lancet 2014; 384: 6-12.

3. Andriole GL, Crawford ED, Grubb RL, et al. Mortality results from a randomized prostate-cancer screening trial. $\mathrm{N}$ Engl J Med 2009; 360: 1310-1319.

4. Mottet N, Bellmunt J, Briers E, et al. Guidelines on prostate cancer. European Associaton of Urology 2015.

5. MulhemE, FulbrightN, Duncan N. Prostate cancer screening. Am Fam Physician 2015; 92: 683-688.

6. Xu J, Janisse J, Ruterbusch JJ, et al. Patients' survival expectations with and without their chosen treatment for prostate cancer. Ann Fam Med 2016; 14: 208-214.

7. Barry MJ, Wexler RM, Brackett CD, et al. Responses to a decision aid on prostate cancer screening in primary care practices. Am J Prev Med 2015; 49: 520-525.

8. Wilkes MS, Day FC, Srinivasan M, et al. Pairing physician education with patient activation to improve shared decisions in prostate cancer screening: a cluster randomized controlled trial. Ann Fam Med 2013; 11: 324-34.

9. Feng B, Srinivasan M, Hoffman JR, et al. Physician communication regarding prostate cancer screening: Analysis of unannounced standardized patient visits. Ann Fam Med 2013; 11: 315-323.
10. Volk RJ, Linder SK, Kallen MA, et al. Primary care physicians' use of an informed decision-making process for prostate cancer screening. Ann Fam Med 2013; 11: 6774.

11. Wilkes M, Srinivasan M, Cole G, et al. Discussing uncertainty and risk in primary care: Recommendations of a multidisciplinary panel regarding communication around prostate cancer screening. J Gen Intern Med 2013; 28: 1410-1419.

12. Myers RE, Daskalakis C, Kunkel EJ, et al. 3rd Mediated decision support in prostate cancer screening: a randomized controlled trial of decision counseling. Patient Educ Couns 2011; 83: 240-246.

13. Maffei RM. Developing a conceptual map of patient information needs in prostate cancer screening. Nurs Inform 2012: 273.

14. McFall SL, Hamm RM, Volk RJ. Exploring beliefs about prostate cancer and early detection in men and women of three ethnic groups. Patient Educ Couns 2006; 61: 109-116.

15. Davis K, Haisfield L, Dorfman C, et al. Physicians' attitudes about shared decision making for prostate cancer screening. Fam Med 2011; 43: 260-266.

16. Woolf SH, Krist AH, Johnson RE, Stenborg PS. Unwanted control: How patients in the primary care setting decide about screening for prostate cancer. Patient Educ Couns 2005; 56: 116-124.

17. Wilt TJ, Brawer MK, Jones KM, et al. Radical prostatectomy versus observation for localized prostate cancer. N Engl J Med 2012; 367: 203-213.

18. Volk RJ, Shokar NK, Leal VB, et al. Development and pilot testing of an online case-based approach to shared decision making skills training for clinicians. BMC Med Inform Decis Mak 2014; 14: 95.

19. Cooperberg MR. Implications of the new AUA guidelines on prostate cancer detection in the U.S. Curr Urol Rep 2014; 15: 420 .

20. Giguere A, Légaré F, Grad R, et al. Decision boxes for clinicians to support evidence-based practice and shared decision making: The user experience. Implement Sci 2012; 7: 72 .

21. Brackett C, Kearing S, Cochran N, et al. Strategies for distributing cancer screening decision aids in primary care. Patient Educ Couns 2010: 78: 166-168.

\section{Correspondence to:}

Miguel Ángel Acosta-Benito, $\mathrm{PhD}, \mathrm{MD}$,

Doctor in Mar Báltico Primary Care Centre, Madrid's Public Health Service, Spain.

Tel: 34661952093

E-mail: maacostabenito@gmail.com 